Utah State University

DigitalCommons@USU

8-31-1973

\title{
Continued Studies of the Status, Socialization, and Relationships of Isle Royale Wolves, 1967-1970.
}

Michael L. Wolfe

Durward L. Allen

Follow this and additional works at: https://digitalcommons.usu.edu/aspen_bib

Part of the Agriculture Commons, Ecology and Evolutionary Biology Commons, Forest Sciences Commons, Genetics and Genomics Commons, and the Plant Sciences Commons

\section{Recommended Citation}

Wolfe, Michael L.; Allen, Durward L. 1973. Continued Studies of the Status, Socialization, and Relationships of Isle Royale Wolves, 1967-1970. Journal of Mammalogy 54(3): 611-635.

This Article is brought to you for free and open access by the Aspen Research at DigitalCommons@USU. It has been accepted for inclusion in Aspen Bibliography by an authorized administrator of DigitalCommons@USU. For more information, please contact

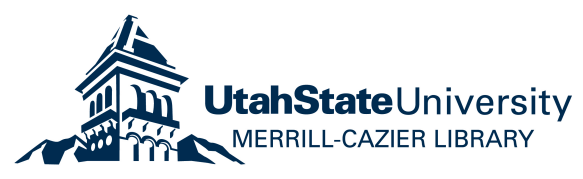




\section{CONTINUED STUDIES OF THE STATUS, SOCIALIZATION, AND RELATIONSHIPS OF ISLE ROYALE WOLVES, 1967 TO 1970}

Michael L. Wolfe and Durward L. Allen 


\title{
CONTINUED STUDIES OF THE STATUS, SOCIALIZATION, AND RELATIONSHIPS OF ISLE ROYALE WOLVES, 1967 TO 1970
}

\author{
Michael L. Wolfe and Durward L. Allen
}

\begin{abstract}
Studies of the wolf (Canis lupus) and its prey in Isle Royale National Park commenced in 1958. Numbers, pack structures, and observed relationships are reported herein for winter periods of the 4 years, 1967 to 1970 . An important feature of the period was the immigration of a pack of seven wolves in 1967. Four of the seven were black and thus identifiable. This addition raised wolf numbers on Isle Royale to at least 28. Through mortality not compensated for by recruitment, and possibly by the egress of a pack of six to Canada, the population was reduced to 15 in 1968. Estimates for the winters of 1969 and 1970 were 17 and 18, respectively. In 2 years considered to be environmentally favorable, there were unexpectedly small population gains toward an earlier mean of 24.

In the period 1967 to 1970 the common size for major packs on the island was six or seven, and evidence is accumulating that the area may not accommodate more than a single breeding group. The smaller packs did not evidence any decrease in predation efficiency relative to that observed for a large pack of 16 prior to 1967. Territorial antagonism, however, between the largest pack and a group of four apparently resulted in a clash in 1969 during which one of the four was killed.

In the winter of 1970 the dominant pack contained eight wolves at the highest count. The alpha male in this pack was a large gray animal that appeared bonded with the same female in 1969 and 1970. The pair was closely attended in 1970 by a large black male that evidently was the beta animal in the male hierarchy.
\end{abstract}

The wolf and its prey in Isle Royale National Park have been under continuing investigation since 1958. A major long-term objective of the studies has been to understand the dynamics of coactions between wolf and moose (Alces alces) in this island ecosystem. The pursuit of such objectives, however, also has provided insight into the hunting techniques and behavior, social organization, breeding patterns, and territoriality of a wolf population that is freeranging but protected and virtually undisturbed.

The initial three years of the program were described by Mech (1966). Jordan et al. (1967) reviewed Mech's findings and detailed subsequent information on wolf numbers and their social structure through the winter of 1966. In 1969, Jordan further described changes in the behavior, social organization, and cohesiveness of the island's dominant wolf pack, and attributed these to the changing role and ultimate death of the pack's alpha male in the winter of 1966. The current account presents the observed succession of events during the period 1967 to 1970 and attempts to interpret their demographic and social implications.

\section{Study Area, Methods, and Conditions}

Michigan's Isle Royale, a roadless island of 544 square kilometers in northern Lake Superior, is approximately 72 kilometers long with a maximum width of about 14 kilometers 


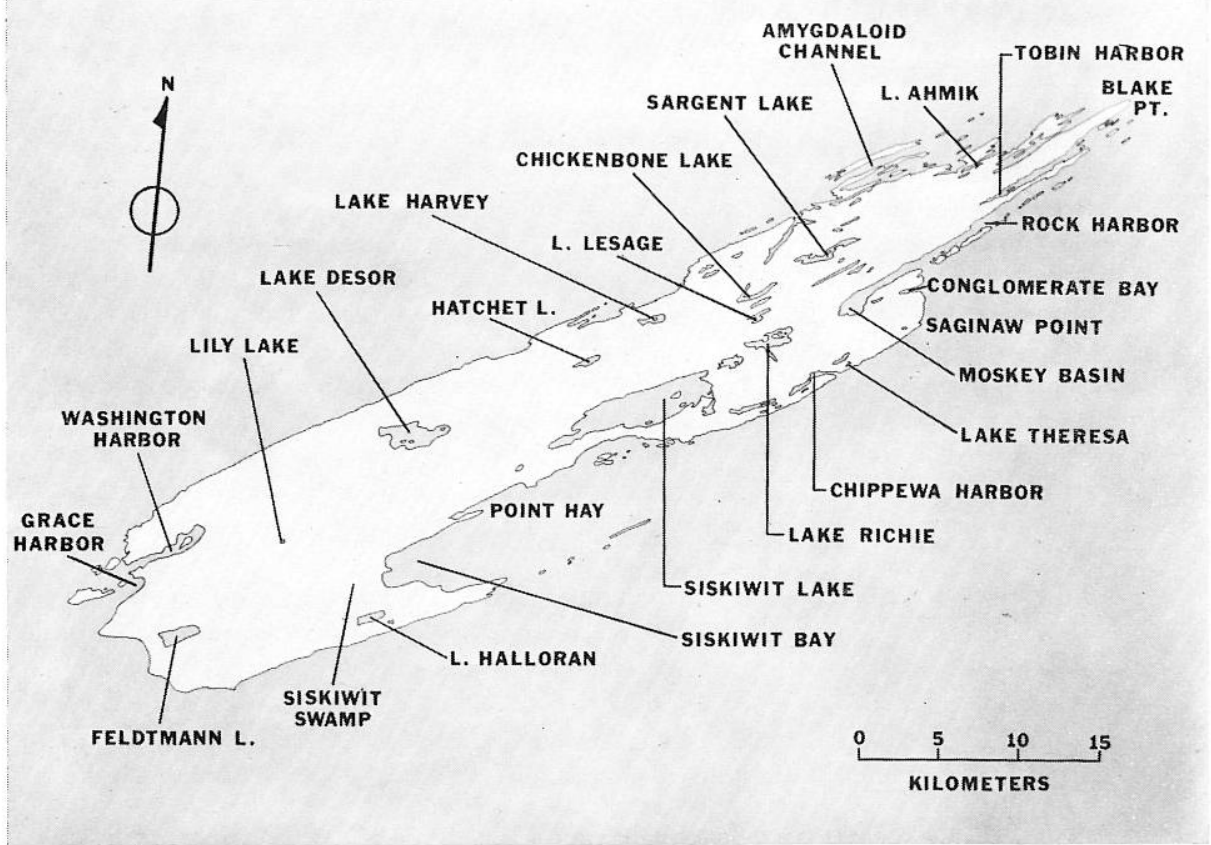

FIG. 1.-Map of Isle Royale, showing locations of natural features referred to in the text.

(Fig. 1). Its history and environmental characteristics have been described by Linn (1957), Mech (1966), and Shelton (1966). Perhaps the most notable biotic feature is the island's limited mammalian fauna, which consists only of some 15 documented species (Johnnson and Shelton, 1960).

Investigational procedures were the same as in earlier years of this study, those described by Mech (1966) and Jordan et al. (1967). Field work in winter was conducted annually during approximately 7 weeks beginning 1 February. References below to a given winter, such as "winter 1967," refer to the winter months of the appropriate biological year (that is, 1966 to 1967). Observations of wolves and moose were made primarily from a ski-equipped aircraft. An Aeronca Champion was used for approximately the first 100 hours of flying each winter and a Piper Super Cub thereafter. During the winters reported on herein, the total number of hours flown were: 1967, 169; 1968, 140; 1969, 131; 1970, 90. Approximately 30 per cent of the total flight time each year was devoted to moose inventories. The remaining time was used to search for wolves and their kills and to observe wolf activities. Wolf sightings in summer were rare, although ground-based field work concerned with moose biology was in progress from the middle of May until late October.

Differentiation of young-of-the-year from adult animals in mid-winter associations remains an important but difficult assignment in field studies of wolves. Although Jordan et al. (1967) concluded that not all pups on Isle Royale are recognizable from the air, they enumerated several morphological and behavioral characters as useful criteria for identifying pups. These include (in comparison with adults): more uniform dorsoventral coloration, fuzzier pelage, stubbier head, shallower trunk, more irregular walking or trotting gait, and immature postures similar to those known in domestic dog pups. While cognizant of their fallibility, we have employed these criteria to distinguish pups. 
TABLE 1.-Weather conditions during Isle Royale winter field work, 1967 to 1970.

\begin{tabular}{|c|c|c|c|}
\hline \multirow[b]{2}{*}{ Year } & \multicolumn{2}{|c|}{ Temperature (Centigrade) } & \multirow{2}{*}{$\begin{array}{l}\text { Snow depth at } \\
\text { Windigo } \\
{\text { (centimeters })^{1}}\end{array}$} \\
\hline & $\begin{array}{l}\text { Mean daily } \\
\text { maximum }\end{array}$ & $\begin{array}{l}\text { Mean daily } \\
\text { minimum }\end{array}$ & \\
\hline \multicolumn{4}{|l|}{1967} \\
\hline (2 February-21 March) & $-7.5^{\circ}$ & $-20.7^{\circ}$ & $58-79 \mathrm{~cm}$ \\
\hline \multicolumn{4}{|l|}{1968} \\
\hline (30 January-17 March) & $-3.4^{\circ}$ & $-15.2^{\circ}$ & $24-38 \mathrm{~cm}$ \\
\hline \multicolumn{4}{|l|}{1969} \\
\hline (31 January-14 March) & $-2.2^{\circ}$ & $-15.4^{\circ}$ & $112 \mathrm{~cm}$ \\
\hline $\begin{array}{l}1970 \\
\text { (29 January-14 March) }\end{array}$ & $-5.3^{\circ}$ & $-18.6^{\circ}$ & $59 \mathrm{~cm}$ \\
\hline
\end{tabular}

${ }^{1}$ First figure is depth at beginning of period; second is the maximum, if greater. Inasmuch as measurements are intended to reflect ground conditions, a new snow was allowed to settle for 2 or 3 days before depth was recorded.

Weather conditions are critical to our effectiveness in the field, and modify activities and distribution of wolves and moose. Recent winters have been characterized by high winds and little fresh snow from late February onward. These conditions affected our ability to track wolves. Commonly the animals follow shorelines, lakes, and other areas of lesser snow depth and better footing. On a heavily crusted snow they circulate freely inland without leaving new tracks and thus can be difficult to locate. During each of the winters of this study ice formed in the channel between Isle Royale and the Canadian islands and mainland, a distance ranging from 21 to 29 kilometers.

The 12-year (1959 to 1970) mean maximum snow accumulation at Washington Harbor on the southwest end of the island was $71.8\left(s_{\bar{x}}=23.2\right)$ centimeters. In these terms, 1967 and 1970 may be considered in the normal range (Table 1). Snow of this depth usually results in a stratification of moose density, with most of the animals frequenting shorelines and lake edges. Such was the pattern of moose distribution observed in 1967 and 1970. Also characteristic of these two winters was a well developed ice shelf on the island's Lake Superior shore, which facilitated wolf travel and hunting activities in such areas.

The winter of 1967 was characterized by the lowest temperatures (Table 1) experienced in 12 years, which caused the 58 to 79 centimeters of snow to be fluffy and of uncertain footing. The snow had settled to 62 centimeters by the third week in March. It appeared that moose used the wind-blown lakes and shores to an unusual degree, but this could not be documented reliably.

While 1968 and 1969 differed greatly in terms of snow depth, both winters were characterized by poorly developed ice on harbors and bays. Wolves traveled inland routes more frequently, especially in 1968 when snow cover was exceptionally shallow.

Ground conditions were of particular significance in 1968. During most of February snow was less than 30 centimeters deep over much of the island, and it was wind-packed with little track registration after the middle of the month. Wolves made mimimal use of their usual travel routes, and sometimes groups or individuals were not seen by observers for many days at a time. The lack of snow cover also exposed ground-level browse on the sides of ridges and other areas that normally were little-used, resulting in a more uniform distribution of moose over the island.

In contrast to the minimal snow cover of 1968, we found an average depth of 112 centimeters in the area of Washington Harbor upon our arrival on 31 January 1969. At 
the east end of the island, the snow depth was 20 centimeters less. There was little ice on the bays, and on inland lakes a slushy layer greatly hindered landings and take-offs.

Water content of the snow varied from 17 to 35 per cent by volume from top to bottom of the profile. Thus lower levels of the snow were more solid, providing moose enough support so they could raise the existing browse line on balsam fir and white cedar-most noticeably along shorelines. Less than 15 centimeters of new snow fell during February and early March, and by 14 March, the snow cover at Windigo had settled to approximately 80 centimeters.

\section{Review of Earlier Events}

From 1959 until 1966, the population of wolves on Isle Royale was characterized by a major, large and dominant pack, commonly numbering 15 or 16, but varying from 11 to 22 (Mech, 1966; Jordan et al., 1967). In the winters of 1959 and 1960 this main pack ranged the entire length of the island. Smaller associations of less than five animals as well as single wolves also were present each year. Usually these were nonbreeding groups that appeared to hold over from year to year, but inasmuch as the wolves were not marked, the identity of individuals is uncertain (Jordan et al., 1967).

During Mech's (1966) first two winters, 1959 and 1960, the large pack was stable. It continued to maintain its number, usually at 15 plus 1 or 14 plus 2 , through the winter of 1963. The added individuals were social subordinates that trailed the pack, usually feeding as scavengers. The eventual fate of such animals is probably to drop off and become true "loners" (Jordan et al., 1967). Subgroups have been seen to split from the main pack for a week or more and then rejoin.

In 1964, following a year of high recruitment, the pack was seen once at an all-time maximum of 22 wolves. Apparently two animals then dissociated permanently, because counts were 20 or less during the remainder of the study period. Number of pups was probably four, possibly more.

By the winter of 1965, the large pack had decreased to 18 or less, with the presence of four pups indicated. One pack was noticeably small and sometimes separate. The social structure of the main pack seemed to have undergone a major rift. A family group of five, consisting of a breeding pair, their pup of the year and two additional members occupied a range at the northeast end of the island and was last seen as a recognizable entity on 27 February. Copulation had been observed, and circumstantial evidence (Jordan et al., 1967) suggested that the pack may have remained in the area to produce a litter in the spring of 1965 . The remains of a pup-evidently a casualty of the preceding autumn or early winter-were found near Conglomerate Bay in the spring of 1966. In February and March of 1966 this sector of the island was frequented by a nonbreeding group of four. Although the dominant male from the previous winter was apparently no longer present, Jordan et al. (1967) assumed that this unit represented the remainder of the original new pack of five. 
When the 1966 winter study began, the large pack numbered only 15 . In early February a subgroup of three separated and did not rejoin during the study period. Three of the remaining 12 wolves commonly trailed the main body of the pack and one of the three seldom joined the larger group.

These events preluded an occurrence of particular social significance in March 1966. For at least the previous 3 years the alpha male had been recognizable by his large size, pale coloration, and dominance behavior (Jordan, 1969). In 1966, this individual became lame and evidently was killed by his associates. When the pack was relocated after 2 weeks of unfavorable flying weather, it comprised only eight animals, the trailing subgroup of three apparently having separated permanently. Subsequently, the remaining unit of eight moved east well beyond its usual range.

\section{Events OF 1967}

Observations in the winter of 1967 (Fig. 2) confirmed a change in the old order. During the first 3 weeks of February a pack of six (Six Pack) was using the east-central portion of the island, and a group of seven (Lily Lake Seven) was at the west end. These seemed likely remnants of the 1966 large pack. Both groups displayed sexual activity. A loose association of four (Tobin Harbor Pack) frequented the easternmost sector of the island. The numerical complement and area of activity of this apparently nonbreeding group suggested that it and the pack of four from the previous winter were one and the same; however sufficient documentation is lacking.

On 5 February 1967 the Six Pack occupied a kill on Lake Theresa (Fig. 2). These wolves were observed at the kill-site on the following 2 days, but had vacated the site by 9 February. They moved 6 kilometers north across the middle of the island, where they killed a calf near Sargent Lake on or before 16 February. They left this kill on 21 February and traveled up Rock Harbor to Blake Point at the northeastern tip of the island. On the following day they were seen for the last time as a unit on the north side of the island 5 kilometers west of Blake Point and traveling southwest. The movements and disappearance of this group probably have particular significance in light of what followed.

The Lily Lake Seven included an identifiable animal, distinguishable by paler shoulders and an unusually pale chevron on its back. The pack was first observed on 17 February at a kill in the vicinity of Lily Lake (Fig. 2); an earlier kill in the Siskiwit Swamp was also attributed to this group. On 22 February the pack vacated the kill at Lily Lake and traveled through the Siskiwit Swamp. They trekked eastward from Lake Halloran the following day and checked the Six Pack's kill on Lake Theresa on the 24th, covering a linear distance of about 35 kilometers. They continued to the east via Rock Harbor another 15 kilometers and on 25 February were seen at the mouth of Tobin Harbor-where the pack of four (or two duos) had appeared to be localized. The Lily Lake Pack then turned back westward, traveling the 


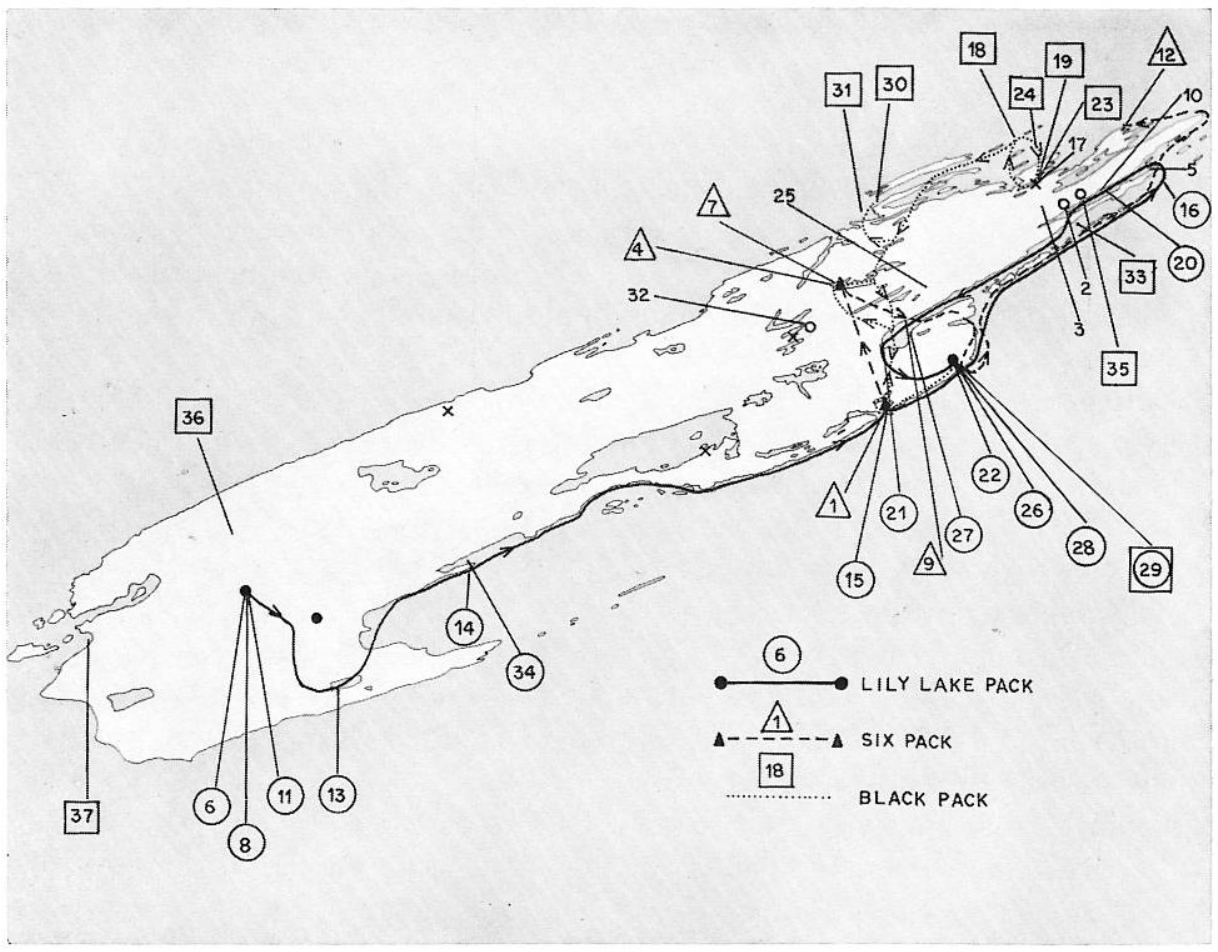

FIG. 2.-Known movements and kills of Isle Royale wolves (major packs) in the winter of 1967 ( 2 February to 5 March). Numbers refer to observations listed in Appendix table 1. Legend: solid lines and circles represent routes and kills, respectively of the Lily Lake Seven; broken lines and triangles indicate movements and kills of the Six Pack; movements of the immigrant Black Pack are designated by dotted lines; unenclosed numbers denote observations of the Tobin Harbor Pack or wolves of unknown affiliation; small open circles are kills of the Tobin Harbor Pack; those of unknown agency are represented by an $\mathrm{x}$.

length of Tobin Harbor, and were observed on the morning of the 26th at the head of Moskey Basin. On the same afternoon they wounded a moose on Saginaw Point but did not kill it until the night of 1 March.

Including at least one loner, a minimum of 18 wolves occupied the northeast quarter of Isle Royale on 24 February. A few other wolves ranged farther west, including a duo around Siskiwit Lake and perhaps two loners. The extended movements and apparent overlap in the ranges of the three major groups of wolves suggested that the winter of 1967 may have been a period of social flux and readjustment.

The apparently unsettled situation was confounded by further events, including the discovery of an injured wolf in its bed 4 kilometers east of Lake Ahmik on the afternoon of 24 February. Shortly thereafter Wolfe and Murray, the pilot, counted six wolves in the woods at the Lake Ahmik kill and logically assumed them to be the Six Pack. 
The following morning, Allen and Murray located seven wolves lying on the ice in outer Amygdaloid Channel. At first sighting these appeared to be the Six Pack, but close examination revealed that four of them were black. Previously there had been no black wolves on Isle Royale, and these animals were at a likely point of arrival for immigrants from Ontario's Sibley Peninsula (a provincial park) to the north. Beyond Steamboat Island (5 kilometers northeast of the main body of the pack) a single wolf was seen running across the ice in the direction of Canada. When the animal was checked closely and photographed, it proved to be bloody on the head. Its actions suggested that it may have been running away from the seven wolves on the ice.

One of the melanistic animals in the newly found association which became known as the Black Pack, had conspicuously paler underparts. Although it was large, its behavior suggested that it might have been a pup. Two of the other black individuals exhibited definite puppish traits. The fourth black wolf was presumably an adult. In close association with the four was a large gray male with unusually blunt facial characters. There was no evident display of dominance by any of the animals at the time of these observations.

The Black Pack was back-tracked to the kill at Lake Ahmik, 3 kilometers to the south, indicating at least a visit there-possibly on the night of the 24th. On 2 March, what may have been an additional injured wolf vacated a bloody bed and moved from the vicinity of the lodges at Rock Harbor, 5 kilometers from Lake Ahmik. This animal limped and had an injured shoulder.

The above evidence, including the unusually numerous sightings of single wolves, suggests that an alien group of wolves crossed the 29 kilometers of smooth ice from Canada and encountered the Six Pack, perhaps near Lake Ahmik. The injured animals and perhaps some nonobserved dead animals could have resulted from such an interaction. In any event, we never saw the Six Pack as a recognizable unit again. A review of observations immediately prior to discovery of the Black Pack calls to question the identity of the six wolves seen on 24 February in the woods at the kill near Lake Ahmik. This may have been an incomplete count of the Black Pack, because the animals could not be examined at close range.

A week after its estimated arrival, the Black Pack traveled south across the island and met part of the Lily Lake Pack at the site of their kill on Saginaw Point. During its movement eastward, the Lily Lake group had lost at least one and possibly two or three of its members, but the remainder of the original association still included the identifiable wolf. On 3 March, 11 wolves were seen in the vicinity of the kill. Eight of the 11, including the four black individuals, were resting at the moose carcass and the remaining three were lying 300 meters distant. No indication of hostility was seen among these animals, an observation later corroborated by careful ground investigations of the area. The following day all had abandoned the site.

The Lily Lake association was not seen as an entity during the remainder of the winter study period. However, the recognizable animal in this association 
was observed with two other wolves on 11 March near Point Hay, 30 kilometers west of the kill site. These wolves undoubtedly represented a remnant of the original Lily Lake Seven.

After dispersal from the kill at Saginaw Point, the Black Pack returned to the north shore at full complement of seven wolves and then split into two groups. One of these, comprising two gray and two black wolves, frequented the northeast end of the island and was observed on various occasions. A second group of three wolves, one of which was black, traveled to the island's southwestern extremity.

Known movements and kills of the Six Pack, the Lily Lake Seven, and the Black Pack in the winter of 1967 are shown in Fig. 2.

In summary, on 17 February 1967 a count of known packs and an estimate of three lone wolves (two certain and the third probable) indicated a total population of 22. A week later the appearance of the Black Pack presumably added seven to this population, less any immediate mortality due to fighting that may have occurred. A good count of wolves could not be made in March, but available sign did not indicate an exceptionally high population-we estimated 25 or 26 .

A total of 12 moose kills were located from the air and all were investigated on the ground. Two calf kills were of undeterminable sex; four of the adults were males and six were females.

\section{Events of 1968}

There may have been two major packs on the island in 1968. We had little opportunity to observe one of the presumed associations, a pack of six including two black wolves. These animals were first sighted on 2 February near a kill by Grace Creek (2.4 kilometers southeast of the head of Washington Harbor). They remained in the area for the next 2 days but apparently had left by 5 February. The animals were next seen (for the last time) at another kill 3 kilometers west of Lake Halloran on 7 February. However, fresh tracks indicated activity by several wolves at the kill-site as late as 12 February Since observations of this pack were made only in relatively heavy cover, it was impossible to ascertain the presence of any pups. However, sexual activity was evident and an attempted mating was witnessed on 7 February, when the six animals were last seen. The north channel froze solidly in the middle of the month and we speculated at the time that these wolves left the island.

A second presumed pack was comprised of seven wolves, including a large black male with paler underparts. These animals constituted the single known breeding group during the remainder of 1968 through 1970, and were designated the Big Pack. Photographs taken each year suggest that the black male was the largest of the three animals thought to be pups at the first observation of melanistic wolves in 1967. Another member of the Big Pack, which was unusually dark dorsally, may have been the third pup in the original 
TABLE 2.-Cranial measurements of adult wolves found on Isle Royale, 1967 to 1969.

\begin{tabular}{lccc}
\hline Necropsy number & 412 & 417 & 436 \\
Date found & $\begin{array}{c}\text { August } 1967 \\
\text { male }^{1}\end{array}$ & $\begin{array}{c}\text { February } \\
\text { male }^{1}\end{array}$ & $\begin{array}{c}1968 \\
\text { Sex }\end{array}$ \\
Cranial measurements & & \\
$\quad$ (in millimeters) & & & \\
Greatest length & 255 & 257 & 256 \\
Condylobasal length & 234 & 239 & 235 \\
Zygomatic breadth & 135 & 135 & 136 \\
Squamosal constriction & 78 & 81 & 80 \\
Rostral width & 41 & 43 & 43 \\
Interorbital breadth & 47 & 46 & 47 \\
Postorbital constriction & 42 & 39 & 40 \\
Mandible length & 182 & 178 & 182 \\
Coronoid process height & 70 & 73 & 72 \\
Maxillary toothrow (crown height) & 104 & 107 & 106 \\
\hline
\end{tabular}

${ }^{1}$ Based on comparison with measurements given in Young and Goldman (1944) for males of the eastern subspecies (C. l. lycaon).

Black Pack. Two gray members of the Big Pack were classified as pups-ofthe-year (that is, about 10 months of age).

A large gray male in the Big Pack of 1968 appeared bonded to a small female and was running at her shoulder on 12 February. This male was the only animal with "flagged" (elevated) tail, indicating dominance (Schenkel, 1947, 1967). The pair was seen in the lead as the wolves traveled and was followed by the large black male. On 13 February the pair was seen coupled, with the black male curled up resting 5 to 10 meters distant.

The Big Pack was first observed on 12 February near the head of Siskiwit Bay. Its tracks were retraced to Hay Bay, suggesting that the wolves had come from farther east. The following morning the seven wolves were observed on a beachline-ridge, 4 kilometers west of the initial sighting. Later that day they were tracked through the Siskiwit Swamp to a new kill-site, located about 5 kilometers east of Feldtman Lake. Because of dense cover and fading light at the time of observation, only four wolves of undetermined color were counted. On the morning of 14 February, however, all seven wolves-including one black animal-were verified at the kill.

High winds precluded flying on the succeeding 4 days and only four gray wolves were seen in the vicinity of the kill on 19 February. Two days later the pack had vacated the area and traveled north to Lily Lake, where it killed another moose and was observed. It was also seen near Lily Lake on 23 and 24 February. Unfavorable flying conditions again intervened and the group was next seen on 29 February at the remains of a moose apparently killed by two other wolves (status uncertain) 10 days earlier. This kill was located 1.3 kilometers north of Lake Desor's westernmost arm. In the interim the 
TABLE 3.-Estimated mid-winter numbers of wolves on Isle Royale, 1967 to 1970.

\begin{tabular}{ccccc}
\hline & \multicolumn{3}{c}{ Wolf population } & $\begin{array}{c}\text { Pups } \\
\text { believed } \\
\text { present }\end{array}$ \\
\cline { 2 - 5 } (February-March $)$ & $\begin{array}{c}\text { Known } \\
\text { minimum }\end{array}$ & $\begin{array}{c}\text { Best } \\
\text { estimate }\end{array}$ & $\begin{array}{c}\text { Possible } \\
\text { maximum }\end{array}$ & - \\
\hline $1967^{\mathrm{a}}$ & 19 & 22 & 23 & 3 \\
$1967^{\mathrm{b}}$ & - & 26 & 30 & $2+?$ \\
$1968^{\mathrm{c}}$ & 21 & 22 & 23 & 2 \\
$1968^{\mathrm{d}}$ & 15 & 16 & 17 & 2 \\
1969 & 14 & 17 & 17 & -1 \\
1970 & 17 & 18 & 18 & -1 \\
\hline
\end{tabular}

Explanation: $a=$ before apparent ingress of the Black Pack; $b=$ after apparent arrival of the Black Pack; $\mathrm{c}=$ prior to presumed egress of six wolves; $\mathrm{d}=$ after presumed egress of these animals; $-1=$ recent death of a wolf.

the Big Pack had made a kill of its own, which was located by back-tracking them 2.6 kilometers south.

The Big Pack remained near Lake Desor for the next 2 days and then moved to Feldtmann Lake by a route undeterminable due to poor tracking conditions. The wolves were seen there on 4 March but a kill near the northeast end of the lake could not be located until 2 days later. After 7 March no wolves were seen at the kill near Feldtmann Lake and the combination of strong winds, warm temperatures, and lack of fresh snow nullified our sighting efforts during the following week. On 13 March, however, part of the Big Pack (four wolves, including one black animal) was seen for the last time that winter at a kill on the same beachline ridge in the Siskiwit Swamp, where the pack had been observed a month earlier.

The discontinuity of observations in the winter of 1968 and the fact that the two presumed pack units were never seen simultaneously pose the question as to whether the pack of six and the Big Pack were not indeed one and the same. This would, of course, negate the case for the presumed egress of the pack of six. Lacking more direct evidence, this point remains speculative. It was our subjective impression that track-sign during the first half of February indicated the presence of two discrete packs at the southwest end of the island. However, an excerpt from Wolfe's field notes, made at the time of the initial observation of the presumed pack of six on 2 February, supports the alternative hypothesis:

"We finally made contact with the group of wolves, suspected to be in the Grace Creek area the day before yesterday. We couldn't locate the kill, but found a group of six (probably seven) wolves on the north side of a small knob about one mile southeast of the Windigo radio tower. Although they were in shadow, one animal appeared to be darker than the rest."

East of the range of the Big Pack, a sector about Lake Lesage and the east end of Siskiwit Lake was frequented by four wolves (sometimes three) that could have represented either the remainder of the Lily Lake Seven or the Tobin Harbor Pack from 1967. These wolves were responsible for at least 


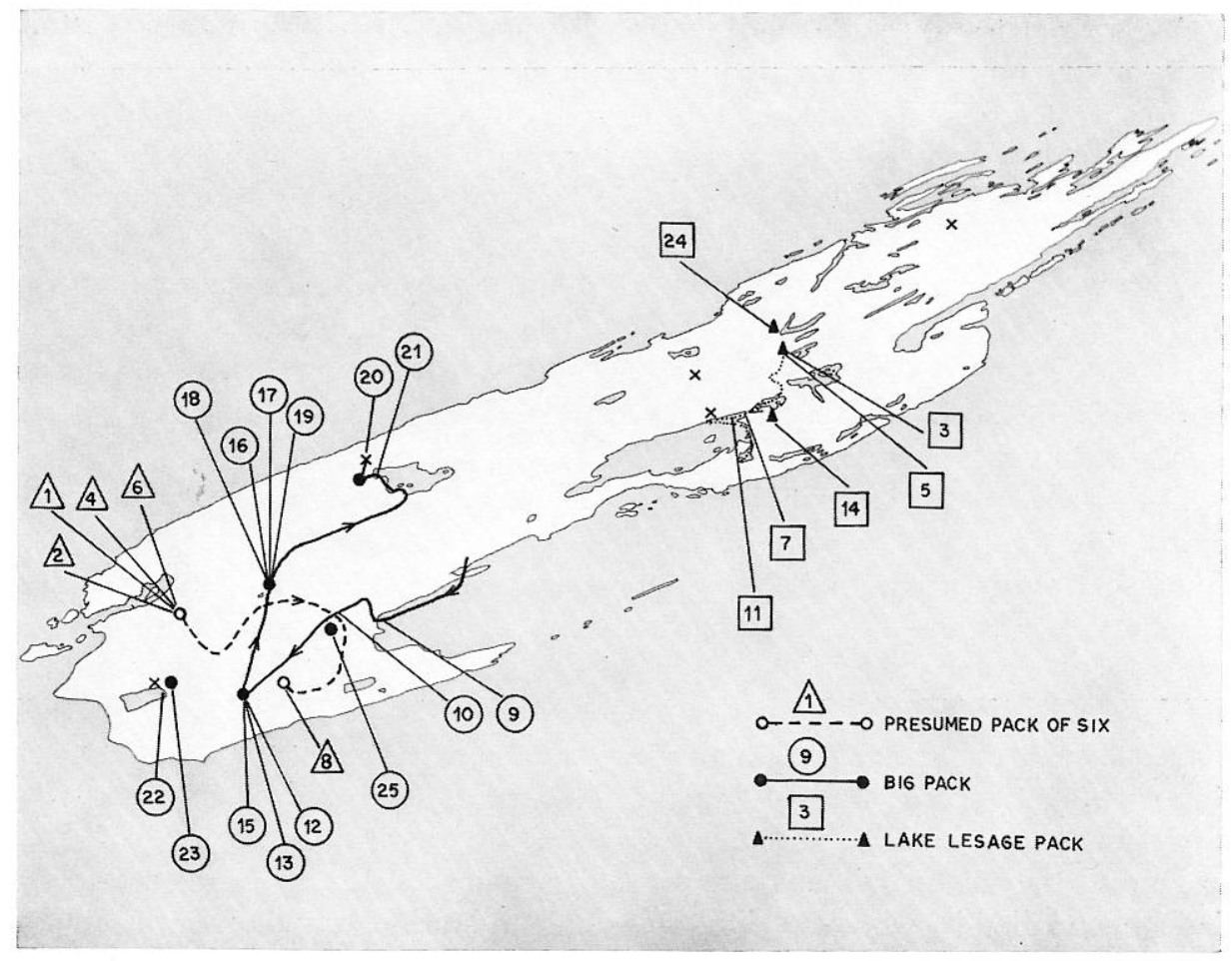

Fig. 3.-Known movements and kills of Isle Royale wolves (major packs) in the winter of 1968 ( 2 February to 13 March). Numbers refer to observations listed in Appendix table 2. Legend: solid lines and circles represent routes and kills, respectively of the Big Pack; broken lines and open circles indicate movements and kills of presumed pack of six prior to its possible egress; movements and kills of the Lake Lesage Pack are designated by dotted lines and solid triangles, respectively; kills of other or uncertain agency are represented by an $\mathrm{x}$.

three kills, near Lake Lesage, Intermediate Lake, and Chickenbone Lake, respectively. Two other old kills in this general locale also were attributed to this pack. Including a duo that frequented the island's northeastern extremity and the aforementioned two wolves (either a duo or two loners) in the vicinity of Lake Desor, the minimum wolf population in the middle of March was 15. With the possible addition of another loner at the extreme southwest end, this was probably near the total for the island (Table 3), unless the pack of six did not really leave the island, in which case the minimum would be 21 .

As already indicated, documentation of wolf activities in 1968 was fragmentary due to unfavorable weather conditions. Known movements of the presumed pack of six, the Big Pack, and the Lake Lesage Pack are shown in Fig. 3. 
Aside from the questionable identity (or presumed disappearance) of the pack of six, mortality undoubtedly contributed to the discrepancy in population estimates for 1967 and the winter following. At least two adult wolves were definitely known to have perished in the interim.

The skull, vertebral column, and pelvic girdle of one animal were discovered in August 1967 by Ranger Zeb V. McKinney on a beach at the southwest end of Washington Harbor. This wolf apparently had died in late winter or early spring of that year. In February 1968, Wolfe and Murray found the skull and upper vertebral column of a second wolf on Point Hay. The animal had probably been dead since the preceding autumn and recently had been unearthed by scavengers.

Both wolves were classified as adult males, on the basis of cranial measurements (Table 2). None of the leg bones from either specimen were found but those skeletal portions recovered had no gross pathology. In neither case was the cause of death ascertainable. Both animals had considerable wear on the canine teeth, but accurate age determination was not possible, because reliable aging criteria for wolves have not yet been reported. Advanced wear of teeth and old age in wolves are not synonymous a priori, inasmuch as the social affiliation and rank of an individual wolf may affect its diet (amount of bone) and hence the degree of wear on teeth.

During the winter of 1968, we located remains of 15 moose presumed to have been killed by wolves. Of the 10 examined on the ground, one was a calf. Of the nine adults, six were males and three were females.

\section{The Winter of 1969}

Three consistent associations characterized the wolf population on Isle Royale in the winter of 1969. The Big Pack, recognizable by the black male, contained nine wolves at first observation on 1 February. Thereafter, it numbered only eight animals for the remainder of the study period. Two of the members showed puppish characteristics, suggesting that a litter had been born in the spring of 1968. The pack had extended its range to include the entire island with the exception of the extreme northeast quarter in 1969. Known movements and kills of this pack are illustrated in Figure 4.

Social organization of the Big Pack appeared to resemble that during the previous winter. The large gray (alpha) male was still bonded to a small female, assumed to be its mate of the year before. The black male occupied a relatively high social status, commonly associating with the dominant pair. Otherwise, the social hierarchy was not clearly defined. Sexual activity was noted on several occasions but copulation was not actually witnessed.

Two additional associations of two and three wolves, which apparently were nonbreeding, frequented the northeast sector of the island during the winter of 1969, largely exclusive of the territory of the dominant pack. Because units of nine, three, and two definitely were recorded, the minimum known popula- 


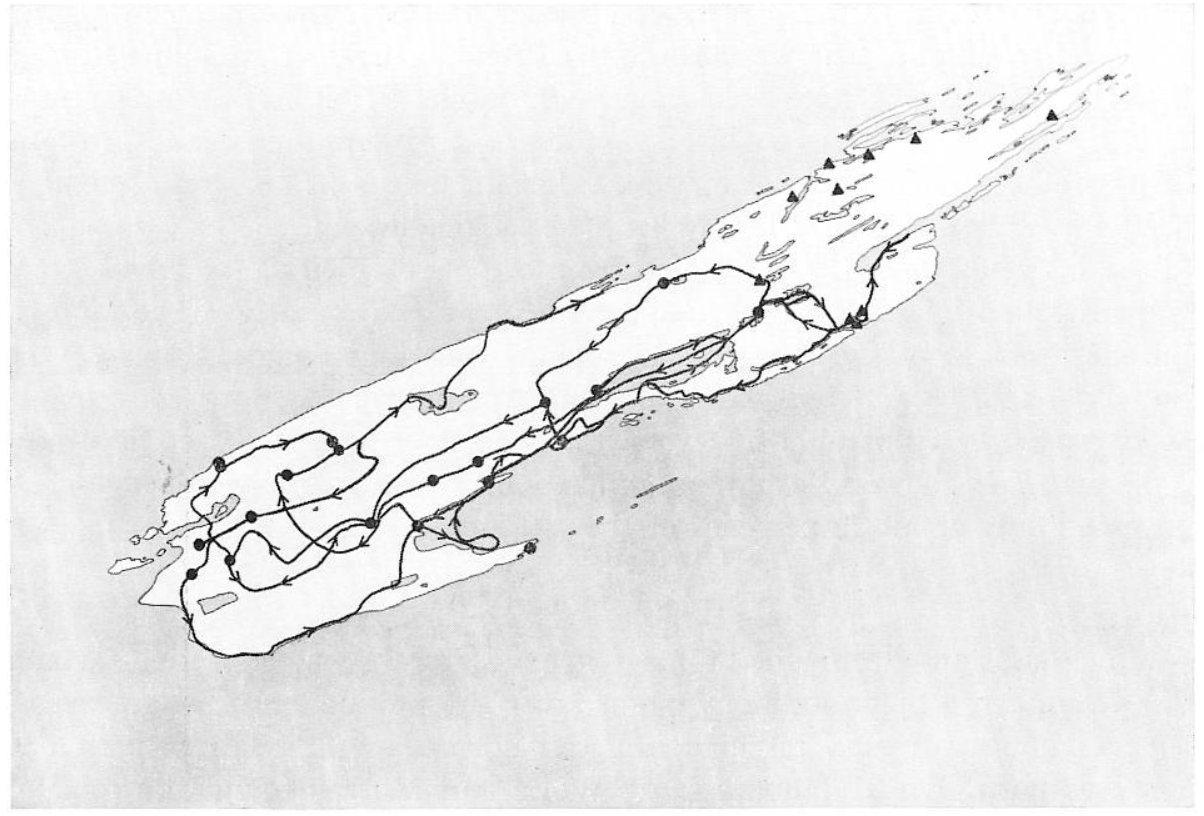

FIG. 4.-Routes and kills of the Big Pack in the winter of 1969 ( 31 January to 6 March). Closed circles represent kills of the dominant pack; those of other groups are indicated by triangles.

tion of wolves was 14. Although no loners were directly identified, tracks indicated the presence of at least two or three such animals and a more accurate population estimate for the island was probably 17 .

On 1 February 1969, Murray and Wolfe saw a dead wolf on the north shore of Chippewa Harbor, in a tracked-up site showing blood spots on the snow. They followed a wolf trail away from this location and about 10 kilometers to the west caught up with nine members of the Big Pack, which was traveling west on Siskiwit Lake.

The dead wolf was retrieved the following day and proved to be an adult male that weighed 37 kilograms. Subsequent necropsy revealed numerous puncture wounds and associated extensive hemorrhaging in the muscles of the right buttocks, posterior sternum, and ventral neck regions. The animal exhibited a slight arthritic impairment (incipient synovitis) in the left scapulohumeral and coxofemoral joints and what was probably a normal Echinococcus (presumed to be granulosus) infection of the small intestine. Old fractures of three ribs also were noted.

The animal had been killed by other wolves in an area representing an eastward extension of the territory of the Big Pack into a zone occupied the previous winter by the Lake-Lesage-Siskiwit group of four. As already noted, the lesser association using that area in 1969 numbered only three. We sur- 
mised that the dead wolf represented a former member of the latter group, an individual that had fallen victim to the Big Pack. In the deep snow the slightly afflicted wolf could have been caught in a chase while the other three escaped. Lacking more conclusive evidence, however, we cannot dismiss the possibility that the animal may have been a lone wolf or even a member of the Big Pack that was killed by his own packmates.

Remains of 30 moose were located from the air in 1969, 20 of which were probably killed by the Big Pack. Of the 19 carcasses examined on the ground, nine were calves of the year and one was a yearling female. Four of the adults were males and five were females. Apparently the deep snow made calves especially vulnerable that year. Also noteworthy is the fact that most of the carcasses showed incomplete utilization; in many cases the wolves had consumed only about 50 per cent of the available flesh.

\section{Winter Period, 1970}

With a substantial amount of meat in cold storage at the end of winter 1969, it appeared that conditions might favor the production of a large yearclass of young wolves. This evidently did not occur, although at least one litter was born. On 31 January 1970, Wolfe and Murray found the remains of a pup on the north shore of Rock Harbor. The carcass had been mostly consumed by foxes, but was not yet completely frozen, suggesting a recent death. The animal was classified as a pup of the previous spring, based on incomplete eruption of the adult canines and only partial ossification of the epiphyseal cartilage (see Mech, 1970). Neither the sex of the animal nor the cause of its death were apparent.

There may have been another young animal in the Big Pack, but this was uncertain. As of the end of the winter study on 14 March, we could not confirm the existence of any living pups of the year, although this may only mean that pups had grown enough so that we could not distinguish them from adults.

In 1970, maximum counts of the Big Pack, which was not located until 19 February, showed eight animals. However, the usual number was seven. The social structure evidently remained much as in 1969, but was more clearly defined. The dominant gray (alpha male) wolf commonly carried his tail flagged, and from 22 February (and possibly before) through the first week of March was bounded with an exceptionally small female-evidently his mate of the previous year. A feature of this pack society in 1970 was the close association of the large black male wolf with the bonded pair. Because all other pack members deferred to the trio, the black individual probably can be regarded as the beta male of the pack. It traveled and rested within 1 to 2 meters of the other two, constantly acknowledging a lower social status through submission postures (Schenkel, 1947, 1967). Three of the other four wolves we commonly observed displayed no overt social ranking among 
themselves, but the fourth animal was definitely the inferior member. It usually maintained a position 30 to 50 meters from the others and was observed regularly with tail tucked. Although copulation was not actually observed, there is little doubt that it occurred and that the dominant gray was the breeding male.

Aside from the pack of eight, which occupied the western half of the island, there was a pack of four in the Richie-Chickenbone area and three in the northeast sector. A duo and a single in the vicinity of Washington Harbor probably were distinct, bringing the total count of wolves to 18 .

In the winter of 1970 we located 22 presumed kills and examined 15 on the ground, of which six were calves. Of eight adults of determinable sex, three were males and five were females. Wolf movements were not sufficiently documented in 1970 to illustrate them.

\section{Discussion}

Our observations of numbers and social relationships of Isle Royale wolves during the winters, 1967 to 1970 are summarized in Table 3 and Fig. 5. Due to the nature of the available evidence, Fig. 5 must be considered as conditional.

Probably the most significant social event during the period 1967 to 1970 was the apparent immigration of the Black Pack in 1967. Results of studies on socialization among captive wolves at the Chicago Zoological Park, Brookfield, (Woolpy, 1967, 1968; Woolpy and Ginsburg, 1967; Rabb et al., 1967) provide a baseline for our interpretation of social implications of our observations after arrival of the alien group on the island.

The exact nature of territoriality in wolves remains open to interpretation (Pimlott et al., 1969), although Mech (1970) has postulated that it may be spatio-temporal. Several investigators (Murie, 1944; Cowan, 1947; Mahrenke, 1971; Mech and Frenzel, 1971) have cited cases of intraspecific intolerance. Previously, wolves on Isle Royale had displayed evident territorial tendencies and instances of intraspecific strife (Mech, 1966; Jordan et al., 1967). Thus antagonism might be expected on the occasion of interpack contact, and an initial violent encounter between the Six Pack and the immigrant Black Pack may be inferred.

The later apparent fraternization of the Black Pack with the Lily Lake Seven is more difficult to interpret. Pimlott et al. (1969: 77) reported observing evidence of the temporary union of packs in Algonquin Park, Ontario, on only four occasions in approximately 900 hours of aerial observation. Conceivably, however, some of the wolves in the two Isle Royale associations in question might have been previously acquainted and possibly related. This could have occurred if one or more wolves from Isle Royale had crossed to Canada in former years and latter returned to the island with offspring. Woolpy and Ginsburg (1967) showed that social bonds among adult wolves- 


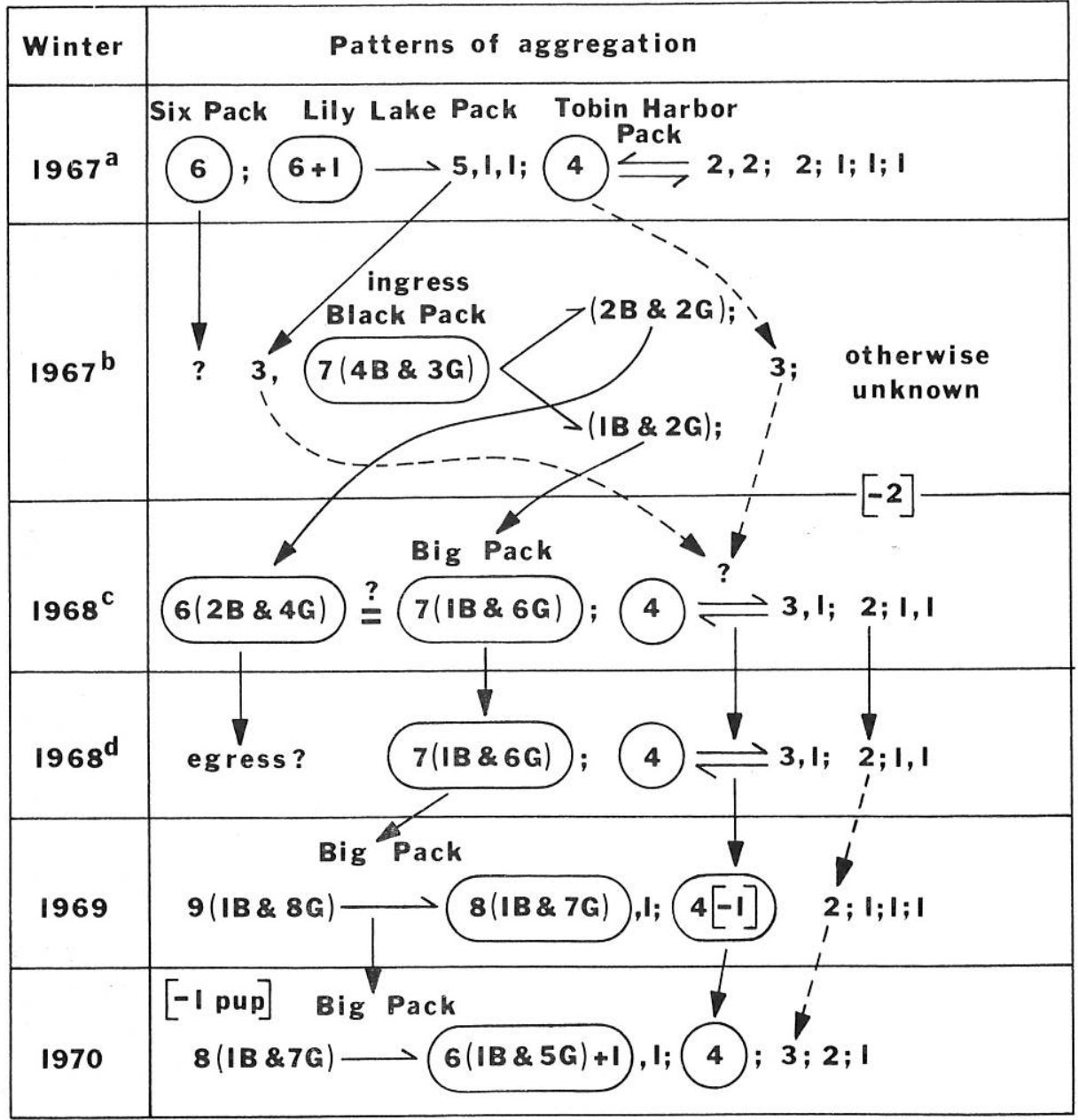

FIG. 5.-Observed and hypothesized mid-winter social relationships in Isle Royale woıves, 1967 to 70. Explanation: basic pack units that were more or less consistently recognizable are encircled; + indicates a trailing wolf; semicolons set off groups not known to join, whereas commas designate groups or subgroups, known to associate but that traveled separately part of the time; open arrows indicate temporary or permanent dissociation of an association during a specific period; solid-tipped arrows show assumed hold-over of group from one period to next; ? represents uncertain status; brackets indicate death of wolf or wolves; $\mathrm{B}=$ black wolf; $\mathrm{G}=$ gray wolf; $\mathrm{a}=$ before apparent ingress of Black Pack; $\mathrm{b}=$ after arrival of Black Pack; $\mathrm{c}=$ before possible egress of presumed pack of six wolves; $\mathrm{d}=$ after assumed egress.

once firmly established--may persist without reinforcement for at least 18 months.

The nature of inheritance of coat color in wolves has not been precisely resolved. Searle (1968) reviewed the findings of earlier investigators (Iljin, 
1941; Kohts, 1948) and concluded that genetically the wolf is normally black agouti, but that no recessive allele for nonagouti seems to be present. Indeed, in domestic dogs, the gene giving self dark pigmentation is dominant over the other alleles in a polyallelic series, which comprises four or more members. Searle (1968: 173-174) further stated that black wolves are common and known to occur in a litter of grays, suggesting that a nonagouti Mendelian factor may be dominant, as it is believed to be in the dog. Thus a gray parent and a black parent may have produced three black pups, if that is indeed what we saw.

The suggested pattern of inheritance tends to refute-barring the possibility of mutation-the supposition that the melanistic wolves in question arose from existing Isle Royale stock. If the allele for agouti coloration is indeed recessive to that for uniform dark coloration, and some of the island's wolves were heterozygous, then probability would dictate that melanistic individuals should have cropped up earlier. As already noted, black animals were unknown on Isle Royale, prior to 25 February 1967. However, the possibility of mutation cannot be totally discounted.

This calls to question the actual fate of the new breeding pack of five, produced in 1965 by a schism of the original large pack. As noted previously, this group was last observed on 27 February at a kill 3 kilometers from the point of Amygdaloid Channel, where the Black Pack was first seen in 1967. On the basis of circumstantial evidence (Jordan et al., 1967), we surmised that a nonbreeding group of four wolves, observed in this area in 1966, represented a hold-over of the group of five, which had lost a member through mortality or other disruption. Another possibility is that the five may have crossed the Lake Superior ice north to the Sibley Peninsula, which was visible from their last known kill-site in 1965. Some members of this association could have returned to Isle Royale 2 years later as part of the Black Pack. Lacking more definitive evidence, however, such a hypothesis remains conjectural.

The 8 years preceding the present study had been characterized by a wolf population varying around a mean of 24 and the presence of a breeding pack, whose usual complement was 16 or 15 plus 1 . When the population or the pack built up beyond these respective levels, numbers declined again, suggesting that critical densities had been reached. It is perhaps significant that the mean population density of wolves on Isle Royale for the period 1959 to 1966 (approximately one animal per 23 square kilometers) represents one of the highest densities reported for the species in the North American literature (Pimlott, 1967).

Observations from 1967 to 1970 indicate that the death of the alpha male in the winter of 1966 marked the end of the original "Big Pack" that had been under observation since 1959. There is strong inference in the numerical history of the Big Pack that the largest aggregation of wolves that can operate efficiently under the moose-beaver economy in an area the size of Isle Royale is probably about 16 . 
The period 1967 to 1970 may be reviewed for parallels or differences with the earlier wolf history of the island. Logical lines of expectation included: reconstruction of the old pack of 16; or in lieu of this, establishment of two or more breeding units. The fact that neither occurred on a durable basis implies that the 12 years of these studies are insufficient to provide an understanding of the precise limitations operating upon the wolf population of Isle Royale. Indeed, social and spatial relationships of the wolves are probably a function of a complex milieu of factors, in which it is not yet possible to separate the effects of changing prey densities, variation in snow conditions, and consequent variation in prey vulnerability as well as the changing status of peripheral packs and possible ingress and egress.

Nonetheless, it has become increasingly evident during these studies that restrictions on breeding constitute an important factor in the regulation of wolf numbers on Isle Royale. Ordinarily only one or two females are actually observed to breed out of perhaps 12 females on the island. Admittedly, this estimate of the total female complement to the population may be inflated. Mech (1970:56) has shown that wolf sex ratios are often biased toward males. Furthermore, six of the seven sexable dead wolves found on the island (those from Jordan et al., 1967 and the present study) have been males. It appears, however, that only a portion of the females in the population actually breed in a given winter. Another factor, probably of equal significance, in the regulation of wolf numbers on Isle Royale is an assumed high mortality rate among pups.

In at least two of the 12 winters, there was at least a second breeding group on the island in February, but in neither case did the situation seem to persist. This suggests that, in social terms, there may not be space or resources for more than one reproductive pack in this island ecosystem. Future work should provide additional data to test the validity of this hypothesis. Our best evidence to date is from the years 1965 and 1968.

An unusually high recruitment of young built numbers of wolves to at least 28 in the period 1964 to 1965. This was followed by a decline due to uncompensated mortality or the possible egress of a second breeding group of five, or both. In February 1967 the ingress of the Black Pack returned the island's population to 28 or more. Again a reduction occurred, evidently through losses and possibly through emigration of a presumed breeding pack of six in 1968. In March of that year only 15 wolves could be accounted for.

To the best of our knowledge this was the lowest number of wolves on Isle Royale in the 12 years of this study. The reduced population in a favorable environmental situation might be expected to have shown a high level of recruitment and a rebuilding of numbers in the years that followed. Instead, the estimates were 17 for 1969 and 18 in 1970.

Breeding by at least one pair of wolves apparently took place in each of the 4 years here reported. During the preceding 8 years (1959 to 1966), the 
large size of the dominant pack commonly led to the complete utilization of kills, which might have been a significant limitation on the amount of carrion available to a breeding pair during the season of pup-rearing after mid-April. Such a limitation could have been involved in a seasonal food shortage and the apparent low survival rate in litters of wolves. In 1969, the exceptional depth and density of the snow cover apparently increased the vulnerability of moose to wolf predation (Telfer and Kelsall, 1971). The associated incomplete utilization of kills by the wolves meant that substantial residues of at least a dozen moose carcasses were available in the spring. Nevertheless, of the only litter known to have been produced, only one pup was known to have lived until late January 1970, and no survival of young beyond that could be established. (However, it is often impossible to distinguish pups at this time of year.) If availability of food is an important factor during rearing of pups, we can only surmise that the unusually large supply of carrion produced by the conditions of the winter of 1969 apparently did not foster survival of pups.

This failure of the wolf population to increase despite apparently good food conditions implies that population control at this density may result more from social than from nutritional factors, contrary to the conclusion of Jordan et al. (1967).

Pack size is a function of both economic and social determinants (Jordan, 1969; Mech, 1970). The reduction in pack size that characterized the period 1967 to 1970 allowed us to test whether the smaller groups experienced a commensurate decrease in predation efficiency when dealing with such a formidable prey species as the moose. Although not extensive, available evidence suggests no such trend. Kill rates for packs of six, seven, and eight in the winters of 1967, 1968, and 1970 approximate one moose per 6 days. This compares favorably with the kill rate (one moose per 3 days), obtained by Mech (1966) for the original large pack of 16 in previous years. The kill rate of the Big Pack in 1969 was appreciably higher (one moose per 3 days) than that for comparable packs in the other 3 years of this study. However, as indicated, a large proportion of the moose killed in that winter were calves and the utilization of adult carcasses was incomplete. Moreover, the unusual snow conditions in 1969 probably increased moose vulnerability, thus producing an atypical situation, just as they had increased the vulnerability of deer (Odocoileus virginianus) in nearby Minnesota in the same winter (Mech and Frenzel, 1971:55-56).

Obviously, kill rates alone do not provide a true measure of predation efficiency. A more reliable index of this parameter might be obtained by determining the ratio of moose killed to those encountered or "tested," as reported by Mech (1966). Unfortunately, information of this nature is unavailable for the period from 1967 to 1970 . We can report, however, that we saw no evidence to support the hypothesis that smaller packs are more selective in their predation (that is, are forced to prey upon older or more vulner- 
able moose than do larger packs). Nor did the incidence of predation on lesser prey species such as beaver (Castor canadensis) and snowshoe hare (Lepus americanus) appear appreciably higher than in previous years. These relationships will be explored in more detail in a future publication.

Indeed, it might be argued that small packs are actually more efficient economic units. As discussed extensively by Mech (1970), a review of the literature pertinent to pack size in other areas of North America and Eurasia reveals that most wolf associations comprise seven or less animals (for example, Makridin, 1962; Pimlott et al., 1969; Pulliainen, 1965; Stenlund, 1955). Thus the original large pack on Isle Royale in former years may be considered to have been an unusually large social unit. Observations of this pack (Mech, 1966) demonstrated that only five or six of the 15 to 16 wolves commonly took an active part in the killing of a moose. By analogy, if the number of wolves actually involved in the killing process is approximately the same in the present smaller groups, then the proportion of free riders is smaller. We concur, therefore, with Mech's (1970) conclusion that although additional individuals may be important in the location, pursuit, and harassment of moose, they do not provide two or three times the advantage over a smaller pack.

Moreover, as hypothesized by Jordan (1969) a high degree of leadership by the dominant animal(s) was probably paramount in the maintenance of the original large pack of 1959 to 1966 at a level at least twice that of an economically optimum complement. When the alpha male ceased to provide the expected degree of leadership, social well being and cohesiveness within the pack declined. The advent of his lameness may have prompted a challenge by one or more of the subordinate animals in which a mortal fight and the death of the alpha male ensued. Circumstantially, the failure of the new Big Pack of 1968 to 1970 to reestablish a unit of approximately equal size would suggest that a comparable degree of social organization has not yet been obtained in this group.

Territorial dominance is an evident characteristic of wolf sociology on Isle Royale, being most convincingly demonstrated when a single major group monopolizes half or more of the island. Within this pack's range, duos or singles survive by avoiding contact. They scavenge on kills, as do foxes (Vulpes vulpes) and ravens (Corvus corax), or they kill moribund moose that have been injured and abandoned by the large pack. A socially less hazardous existence probably is led by the loners or small groups that occupy other parts of the island, although these wolves must kill their own moose. As suggested in 1969, the margin of the large pack's territory is a zone of tension where an individual from a smaller neighboring pack may be caught and killed.

Quite possibly wolves on Isle Royale displayed the same intolerance toward coyotes (Canis latrans) that is evident in their relations with conspecifics (Mech, 1966: 160). Coyotes evidently became established on the island at 
about the same time as the moose, in the first decade of the century (Krefting, 1969). The last coyote track was seen in February 1957 by J. E. Cole of the National Park Service, less than 10 years after wolves came to Isle Royale (Hakala, 1954; Mech, 1966). For 40 years coyotes probably lived mostly on the natural turnover of superannuated animals from the moose herda carrion resource for which only the fox was an important competitor. After the advent of the wolves, the scavenging of both the smaller canids logically would extend to the remains of wolf kills. Being larger and therefore more of a competitor, the coyote may have been killed off directly by the wolf, whereas the fox continues to thrive.

Territorial adaptations apparently require time to develop, and relationships between packs are conditional. In the winter of adjustment after dissociation of the original large pack in 1966, no antagonisms were noted between the two resident packs of six and seven. Although no direct contact was actually observed, the ranges of these groups, which with little question included some wolves that were related and recently associated, showed considerable spatial overlap and the wolves appeared to behave with a degree of mutual tolerance. The Black Pack of 1967-initially assumed to be totally alien-apparently did associate with the Lily Lake Pack, and this association evidently led to an eventual reorganization in which the identity of both groups was lost. An apparently nonbreeding unit of four wolves frequented the extreme northeastern tip of the island in 1966, and for the next 4 years a seemingly casual association of four was found in the eastern third of Isle Royale, sometimes foraying as far west as Siskiwit Lake. There were not necessarily the same wolves; in fact, one member of the presumed original 1969 foursome probably was killed, but four appeared again in that area in 1970 .

Many unknowns could be eliminated if individual wolves and packs could be identified from the air in more than certain exceptional cases. This has raised the question of using radio telemetry to mark at least an animal or two in each group as described by Kolenosky and Johnston (1967). In this respect, a major problem is posed by Isle Royale being a roadless habitat and our winter work having to depend on air transportation. If wolves were trapped or snared, it would probably need to be done at strategically located kills, and it would be necessary to check such sets frequently. Because unfavorable weather often suspends flying for several days at a time, injury to or loss of trapped wolves would be likely. Further, in dealing with a small population of wolves in a park that accommodates steadily increasing numbers of visitors in the summer, it has been deemed advisable to avoid interference with the animals as much as possible.

As the work on Isle Royale proceeds, perennial variations in weather and other conditions can be depended upon to continue to evoke responses from the wolf and its prey. These annual observations should at least help to further define the basic dynamics of this insular community. 


\section{ACKNOWLEDGMENTS}

Major financial support for this work was received from the National Science Foundation (grants GB-5124 and GB-8096 to Allen), the National Park Service, and the Wildlife Management Institute. This is Purdue AES paper no. 4454.

We are particularly indebted to Donald E. Murray of Mountain Iron, Minnesota, whose steadily increasing skill as pilot-observer has been a major factor in the progress of these studies since their inception. In the winter of 1970 , John C. Keeler, a January graduate of the Purdue Wildlife Science curriculum, gave valuable field assistance. Each winter we benefited from the help of various staff members of Isle Royale National Park, who took tours of duty in turn, for a week or more on the island. We also are grateful to Dr. Jerome H. Woolpy for valuable assistance and advice in our interpretation of the social implications of field observations. Finally, we thank Dr. Allen W. Stokes and Miss Lois Cox for their critical review of the manuscript.

\section{Literature Cited}

Cowan, I. McT. 1947. The timber wolf in the Rocky Mountain National Parks of Canada. Canadian J. Res., 25:139-174.

Hakala, D. R. 1954. Wolf on Isle Royale. Nature Mag., 47:35-37.

Hickie, P. F. undated (1943). Michigan moose. Michigan Dept. Cons., Game Div., 57 pp. ILjIN, N. A. 1941. Wolf-dog genetics. J. Genetics, 42:359-414.

JorDAN, P. A. 1969. Leadership and group response in timber wolves: a socio-ecological analysis. Paper presented at 1969 annual meeting of Rural Soc. Soc., San Francisco, August 31, 33 pp. (mimeographed).

Jordan, P. A., P. C. Shelton, and D. L. Allen. 1967. Numbers, turnover, and social structure of the Isle Royale wolf population. Amer. Zoologist, 7:233-252.

Johnnson, R. G., and P. C. Shelton. 1960. The vertebrates of Isle Royale National Park. Wolf's Eye 4(3):1-24 (publ. Isle Royale Nat. Hist. Assoc.).

Kонтs, A. 1948. A variation of colour in the common wolf and its hybrids with domestic dogs. Proc. Zool. Soc. London, 177:784-790.

Kolenosky, G. B., And D. H. Johnston. 1967. Radio-tracking timber wolves in Ontario. Amer. Zoologist, 7:289-303.

Krefting, L. W. 1969. The rise and fall of the coyote on Isle Royale. Naturalist, 20: 24-31.

Lins, R. M. 1957. The spruce-fir, maple-birch transition in Isle Royale National Park, Lake Superior. Unpublished Ph.D. thesis, Duke Univ., 101 pp.

Makridin, V. P. 1962. The wolf in the Yamal north. Zool. Zhur., 41:1413-1417.

MARHENKe, P. 1971. An observation of four wolves killing another wolf. J. Mamm., 52:630-631.

Mech, L. D. 1966. The wolves of Isle Royale. U.S. Nat. Park Serv., Fauna Ser., 7: xiv $+1-210$.

1970. The wolf: the ecology and behavior of an endangered species. Natural History Press, Doubleday, New York, xx +389 pp.

Mech, L. D., AND L. D. Frenzel, Jr. (eds.). 1971. Ecological studies of the timber wolf in northeastern Minnesota. USDA Forest Serv., Res. Paper, NC-52, 62 pp.

Murie, A. 1944. The wolves of Mount McKinley. U.S. Nat. Park Serv., Fauna Ser., $5: x i x+1-238$.

Prмlotт, D. H. 1967. Wolf predation and ungulate populations. Amer. Zoologist, 7: 267-278.

Pimlott, D. H., J. A. Shannon, and G. B. Kolenosky. 1969. The ecology of the timber wolf in Algonquin Provincial Park. Ontario Dept. Lands and Forests, Res. Rept. (Wildlife no. 87), 92 pp. 
Pulliainen, E. 1965. Studies of the wolf (Canis lupus L.) in Finland. Ann. Zool. Fenn., 2:215-259.

Rabb, G. B., J. H. Woolpy, and B. E. Ginsburg. 1967. Social relationships in a group of captive wolves. Amer. Zoologist, 7:305-311.

Schenkel, R. 1947. Ausdrucks-Studien an Wolfen. Behaviour, 1:81-129.

1967. Submission: its features and functions in the wolf and dog. Amer. Zoologist, 7:319-329.

Searle, A. G. 1968. Comparative genetics of coat colour in mammals. Logos Press, Plainfield, New Jersey, xii +308 pp.

Shelton, P. C. 1966. Ecological studies of beavers, wolves, and moose in Isle Royale National Park, Michigan, Unpublished Ph.D. thesis, Purdue Univ., 308 pp.

Stenlund, M. H. 1955. A field study of the timber wolf (Canis lupus) on the Superior National Forest, Minnesota. Minnesota Dept. Conserv. Tech. Bull., 4:1-55.

Telfer, E. S., And J. P. Kelsall. 1971. Morphological parameters for mammal locomotion in snow. Paper presented at 51st Annual Meeting, Amer. Soc. Mamm., Univ. British Columbia, Vancouver, June 1971, 10 pp. (mimeographed).

Woolpy, J. H. 1967. Socially controlled systems of mating among wolves and other gregarious animals. Unpublished Ph.D. thesis, Univ. Chicago, $71 \mathrm{pp}$.

- 1968. Socialization of wolves. Science and Psychoanalysis, 12:82-94.

Woolpy, J. H., And B. E. Ginsburg. 1967. Wolf socialization: a study of temperament in a wild social species. Amer. Zoologist, 7:357-363.

Young, S. P., And E. A. Goldman. 1944. The wolves of North America. Amer. Wildlife Inst., Washington, D.C., $\mathrm{xx}+636 \mathrm{pp}$.

Department of Forestry and Conservation, Purdue University, Lafayette, Indiana 47907 (present address of Wolfe: Department of Wildlife Science, Utah State University, Logan, 84321). Accepted 9 October 1972. 


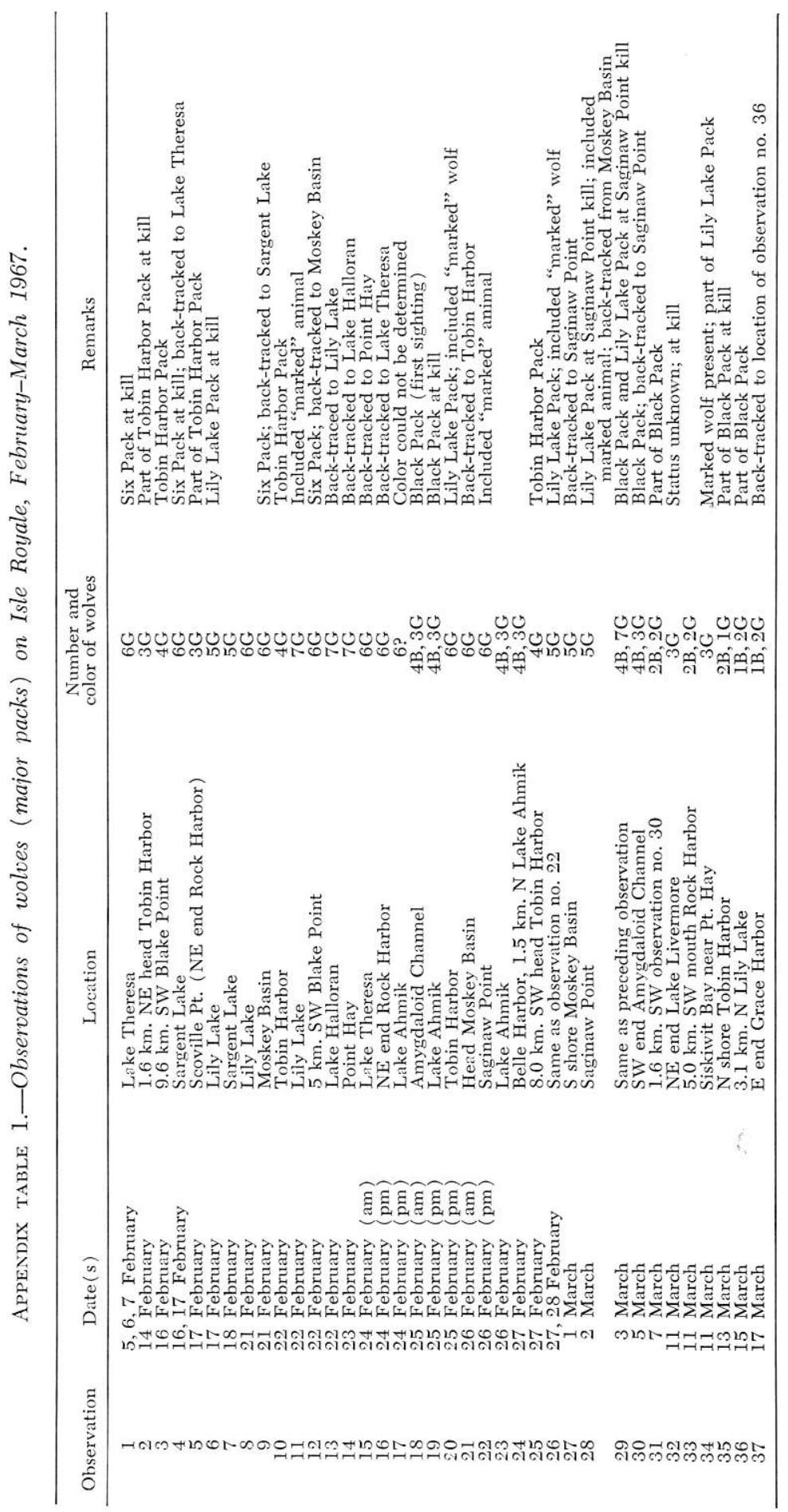




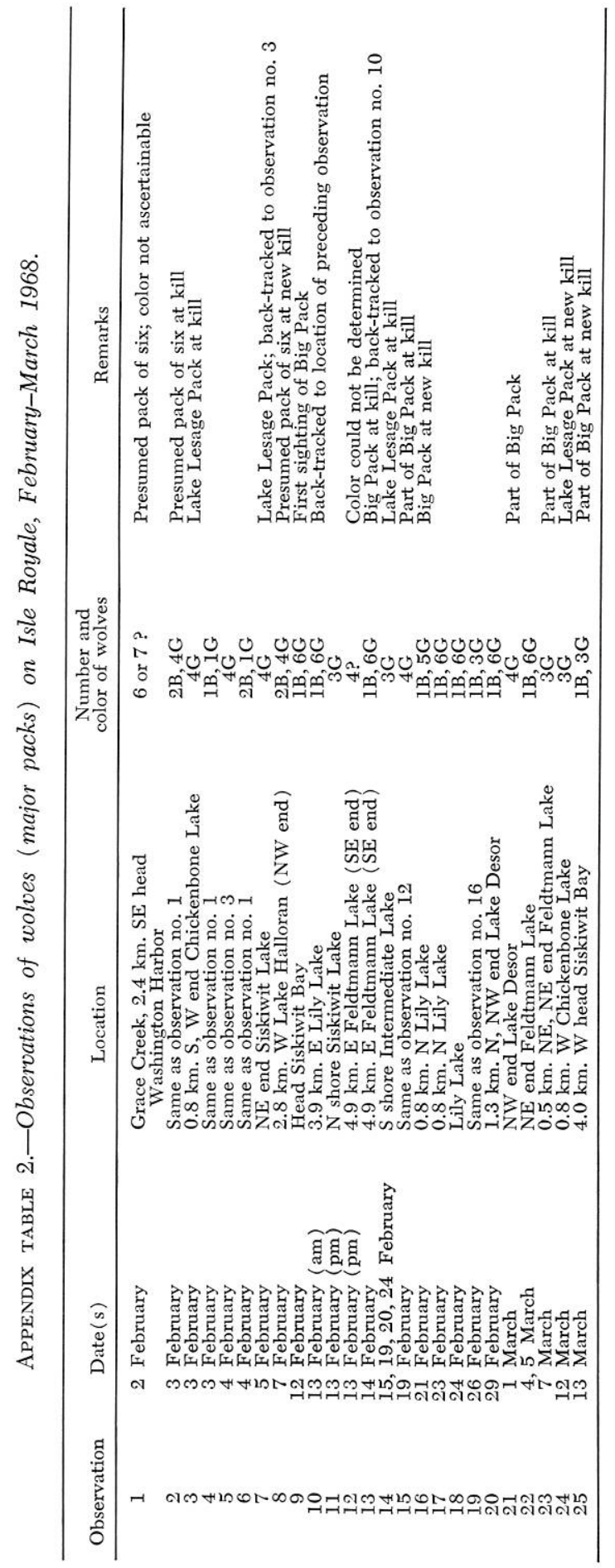


